Д-р техн. наук Г. М. Шабанова, кандидати техн. наук А. М. Корогодська (УкрДАЗТ), Т.Д. Рищенко (ХНАМГ), асп. Р. М. Ворожбіян (НТУ «ХПІ»)

G.M. Shabanova,A.M. Korogodska, T.D. Ryschenko, R.M. Vorozhbiyan

\title{
ВИСОКОЕФЕКТИВНІ СПЕЦІАЛЬНІ В'ЯЖУЧІ МАТЕРІАЛИ НА ОСНОВІ ЛУЖНОЗЕМЕЛЬНИХ ОКСИДІВ
}

\section{SPECIAL HIGH BINDING MATERIALS ON THE BASIS OF ALKALINE EARTH OXIDE}

Вступ. Якість та експлуатаційні характеристики спеціальних в'яжучих матеріалів, які застосовуються для виготовлення бетонів та неформованих матеріалів, створюють необхідність розробки нових складів спеціальних цементів, які зможуть забезпечити надійну та довговічну роботу виробів. Для виготовлення бетонів спеціального призначення використовуються дефіцитні в'яжучі речовини, а цементи, які одержані 3 дешевих матеріалів, обмежуються невисоким терміном експлуатації [1-3].

Актуальність. Основою для створення спеціальних гідравлічних в'яжучих матеріалів можуть бути силікати та алюмінати кальцію в поєднанні 3 тугоплавкими бінарними сполуками. При потужному використанні сировинних ресурсів при виробництві в'яжучих матеріалів зменшуються запаси якісної сировини, тому постає проблема розширення сировинної бази України за рахунок використання відходів хімічного, металургійного та інших виробництв. Актуальне вирішення питання створення ресурсозберігаючих технологій спеціальних цементів та бетонів на їх основі $\epsilon$ сучасною задачею, що також сприяє поліпшенню екологічної ситуації промислових регіонів України.
Основна

частина.

При безперервному споживанні природної сировини у виробництві цементу все менше залишається відносно чистих сировинних джерел. Поблизу заводів необхідні вапняки, як правило, вироблені. Застосування доломітизованих вапняків 3 підвищеним вмістом оксиду магнію може знизити міцність цементу та призвести до руйнування споруди через спізнену гідратацію оксиду магнію у бетоні [4-8]. 3 цього виникає необхідність використання у виробництві в'яжучого, відходів виробництва Горлівського ВАТ “Концерн Стірол", на якому накопичилося більше 20 тис. тонн відходів водоочищення, які утворилися в результаті очищення стічних вод хімічним методом нейтралізації.

Стічні води, які містять неорганічні домішки, необхідно очищати перед тим, як скинути їх до водоймищ, перед використанням їх в технологічних процесах проводять нейтралізацію. Нейтральними $\epsilon$ води, які мають $\mathrm{pH}=6.5-8.5$.

Нейтралізацію можна проводити різноманітними шляхами: змішуванням кислих та лужних стічних вод, добавкою реагентів, фільтруванням кислих вод крізь нейтралізуючі матеріали, абсорбцією кислих газів лужними водами або абсорбцією аміаку кислими водами. 
Осад карбонату кальцію осаджується в циркуляційній камері за допомогою фізико-хімічних методів аналізу проведені дослідження фазового та хімічного складу відходів. За даними хімічного аналізу склад відходів такий, мас. \%: $\mathrm{CaCO}_{3}-75,0-85,0$; $\mathrm{MgCO}_{3}-3,0-9,0 ; \mathrm{Fe}_{2} \mathrm{O}_{3}-4,5-8,5 ; \mathrm{CaSO}_{4}$ $-1,5-3,0 ; \mathrm{SiO}_{2}-5,0-9,0$.
Проведені дослідження відходів водоочищення, результати яких наведено на рис. 1.

На рентгенограмі ідентифікуються дифракційні максимуми, які відповідають сполукам $\mathrm{CaCO}_{3}(3.853 ; 3.033 ; 2.492 ; 2.281$; $2.031 ; 1.924 ; 1.91 ; 1.871 ; 1.602 \AA), \mathrm{MgCO}_{3}$ $(2.737 ; 1.697 ; 2.091 ; 2.492 \AA)$.

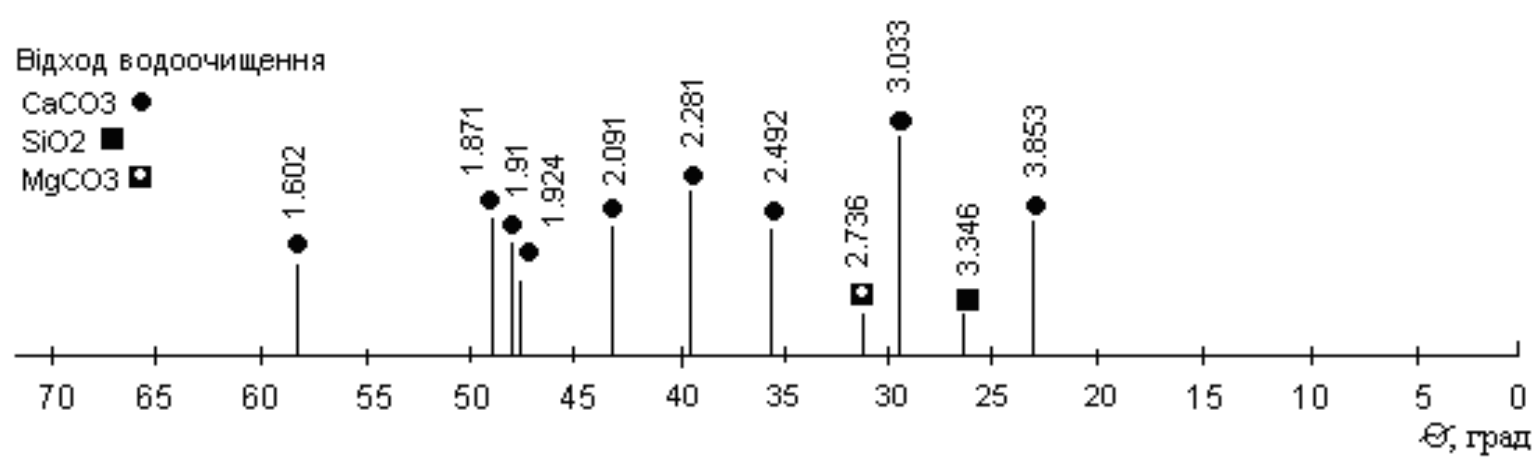

Рис. 1. Рентгенографічні дослідження відходів водоочищення

Таким чином, проведені фізикохімічні методи аналізу відходів водоочищення дозволили зробити висновок, що основними сполуками, які входять до складу відходів, $є$ карбонати кальцію та магнію, які можуть бути використані як сировинні матеріали для виробництва спеціальних цементів.
Для дослідження використовувалися сировинні матеріали: відходи водоочищення Горлівського ВАТ "Концерн Стірол”, технічний глинозем марки Г-00 (ДСТУ 69-12-94), хімічний склад яких наведено в табл. 1, хімічний склад клінкеру подано в табл. 2.

Хімічний склад сировини

\begin{tabular}{|l|c|l|l|l|l|r|l|}
\hline \multirow{2}{*}{ Сировина } & \multicolumn{7}{|c|}{ Вміст оксидів, мас \% } \\
\cline { 2 - 9 } & $\mathrm{CaO}$ & $\mathrm{MgO}$ & $\mathrm{Fe}_{2} \mathrm{O}_{3}$ & $\mathrm{SiO}_{2}$ & $\mathrm{R}_{2} \mathrm{O}$ & $\mathrm{Al}_{2} \mathrm{O}_{3}$ & в.п.П. \\
\hline Відходи & 41,29 & 7,78 & 2,98 & 2,98 & 0,67 & - & 41,74 \\
\hline Глинозем & - & - & 0,05 & 0,06 & 0,43 & 98,46 & 1,00 \\
\hline
\end{tabular}

Таблиця 2

Хімічний склад клінкеру

\begin{tabular}{|c|c|c|c|}
\hline \multirow{2}{*}{$№$} & \multicolumn{3}{|c|}{ Хімічний склад, мас \% } \\
\cline { 2 - 4 } & $\mathrm{CaO}$ & $\mathrm{MgO}$ & $\mathrm{Al}_{2} \mathrm{O}_{3}$ \\
\hline 1 & 31,93 & 2,83 & 65,24 \\
\hline 2 & 28,38 & 5,66 & 65,96 \\
\hline 3 & 24,84 & 8,49 & 66,67 \\
\hline
\end{tabular}


Для оптимізації технологічних параметрів синтезу була виготовлена сировинна суміш у кількості 3 кг, яка мала склад: відходи - 49,15 мас. \% та технічний глинозем - 50,85 мас. \%.

Сировинні матеріали були взяті у відповідному співвідношенні, подрібнення відбувалось у фарфоровому кульовому млині до повного просіювання крізь сито № 008 (вологість суміші складала 4050 мас. \%), потім висушувалася при температурі $100-110{ }^{\circ} \mathrm{C}$, формували зразки діаметром 50 мм та висотою 50 мм на гідравлічному пресі.

Синтез зразків здійснювався у криптоловій печі при заданих температурах та ізотермічній витримці.
Швидкість підняття температури в печі - 50-70 гр/хв, вимір температури здійснювався за допомогою оптичного пірометра. Після випалу зразки мололися до повного просіювання крізь сито № 008.

Були проведені фізико - механічні випробування синтезованих цементів. Визначено на зразках, виготовлених $з$ тіста нормальної крутості, міцність цементів. Випробування відбувалися згідно 3 методикою малих зразків, розробленою M.I. Стрелковим.

Твердіння зразків відбувалось у вологих умовах 2, 7 та 28 діб, після чого були проведені випробування на міцність. Результати випробувань наведено у табл. 3.

Таблиця 3

Оптимізація технологічних параметрів синтезу цементу

\begin{tabular}{|c|c|c|c|c|c|}
\hline \multirow{2}{*}{$o$} & \multirow{2}{*}{$\begin{array}{c}\text { Температура } \\
\text { синтезу, C }\end{array}$} & Ізотермічна витримка, & \multicolumn{3}{|c|}{ Межа міцності на стиск, МПа } \\
\cline { 4 - 6 } & год & 2 доби & 7 діб & 28 діб \\
\hline 1 & 1200 & 3 & - & 20,5 & 25,0 \\
\hline 2 & 1300 & 3 & 34,8 & 52,6 & 60,0 \\
\hline 3 & 1400 & 3 & 61,0 & 79,4 & 82,0 \\
\hline
\end{tabular}

Як видно 3 поданих результатів, оптимальними параметрами синтезу цементу 3 використанням відходів водоочищення є температура $-1400{ }^{\circ} \mathrm{C}$ та ізотермічна витримка при максимальній температурі - 3 години. Водоцементне відношення та нормальну крутість цементу визначали на приладі Віка. Твердіння виготовлених зразків (хімічний склад яких наведено в табл. 2.) здійснювалося у вологих умовах 3 наступним випробуванням після 2, 7 та 28 діб твердіння. Результати випробувань наведено в табл. 4.

Таблиця 4

Фізико-механічні властивості цементу

\begin{tabular}{|c|c|c|c|c|c|c|}
\hline \multirow{2}{*}{ № } & \multirow{2}{*}{ В/Ц } & \multicolumn{2}{|c|}{ Термін тужавіння год-хв } & \multicolumn{3}{|c|}{ Границя міцності на стиск, МПа } \\
\cline { 3 - 7 } & & початок & кінець & 3 доби & 7 діб & 28 діб \\
\hline 1 & 0,25 & $0-50$ & $1-45$ & 61,0 & 79,4 & 82,0 \\
\hline 2 & 0,25 & $1-10$ & $2-00$ & 48,6 & 65,6 & 70,2 \\
\hline 3 & 0,25 & $1-20$ & $2-10$ & 42,8 & 58,4 & 61,4 \\
\hline
\end{tabular}


Як видно 3 наведених даних, усі розроблені склади цементів належать до гідравлічних в'яжучих речовин 3 низьким водоцементним відношенням (0.25), $\epsilon$ швидкотужавіючими (термін тужавіння: початок 50 хв - 1 год $20 \mathrm{xв;} \mathrm{кінець} \mathrm{-} 1$ год 45 хв - 2 год 10 хв), швидкотвернучими (границя міцності на стиск при 2 добах твердіння 40-60 МПа) та високоміцними (границя міцності на стиск після 28 діб твердіння 61,4 - 82 МПа).

Проведені петрографічні дослідження підтвердили вміст у клінкері алюмінатів кальцію різної основності. У зразку під поляризаційним мікроскопом $\epsilon$ безкольорові призматичні кристали із показниками $\mathrm{Ng}=1,663$ і $\mathrm{Np}=1,643$, які від- повідають $\mathrm{CaAl}_{2} \mathrm{O}_{4}$ вмісту 60 - 65 мас \%. Також спостерігаються зерна безбарвні, призматичні кристали, пластинки 3 показником заломлення $\mathrm{Ng}=1,652$ i $\mathrm{Np}=1,618$, які відповідають $\mathrm{CaAl}_{4} \mathrm{O}_{7}$, їх у клінкері $\sim 20-25$ мас \%, а також зерна магнезіальної шпінелі 6-8 мас \%.

На рентгенограмі клінкеру (рис. 2) встановлено, що основними клінкерними мінералами $є \mathrm{CaAl}_{2} \mathrm{O}_{4}(4,67 ; 4,044 ; 3,712$; 3,$195 ; 3,06 ; 2,971 ; 2,873 ; 2,85 ; 2,533 ; 2,516$; 2,$44 ; 2,418 ; 2,40 ; 2,265 ; 2,194 ; 2,132 ; 2,925$ $\AA), \mathrm{CaAl}_{4} \mathrm{O}_{7}(4,67 ; 4,45 ; 3,604 ; 3,503 ; 3,06$; 2,$873 ; 2,759 ; 2,71 ; 2,598 ; 2,533 ; 2,44 ; 2,40$; $2,194 ; 1,799 \AA), \mathrm{MgAl}_{2} \mathrm{O}_{4}(4,67 ; 2,85 ; 2,44$; $2,337 ; 2,022 ; 1,66 \AA)$, а також $\mathrm{CaAl}_{2} \mathrm{O}_{6}$ $(1,961 ; 1,916 ; 1,56 ; 1,557 \AA)$.

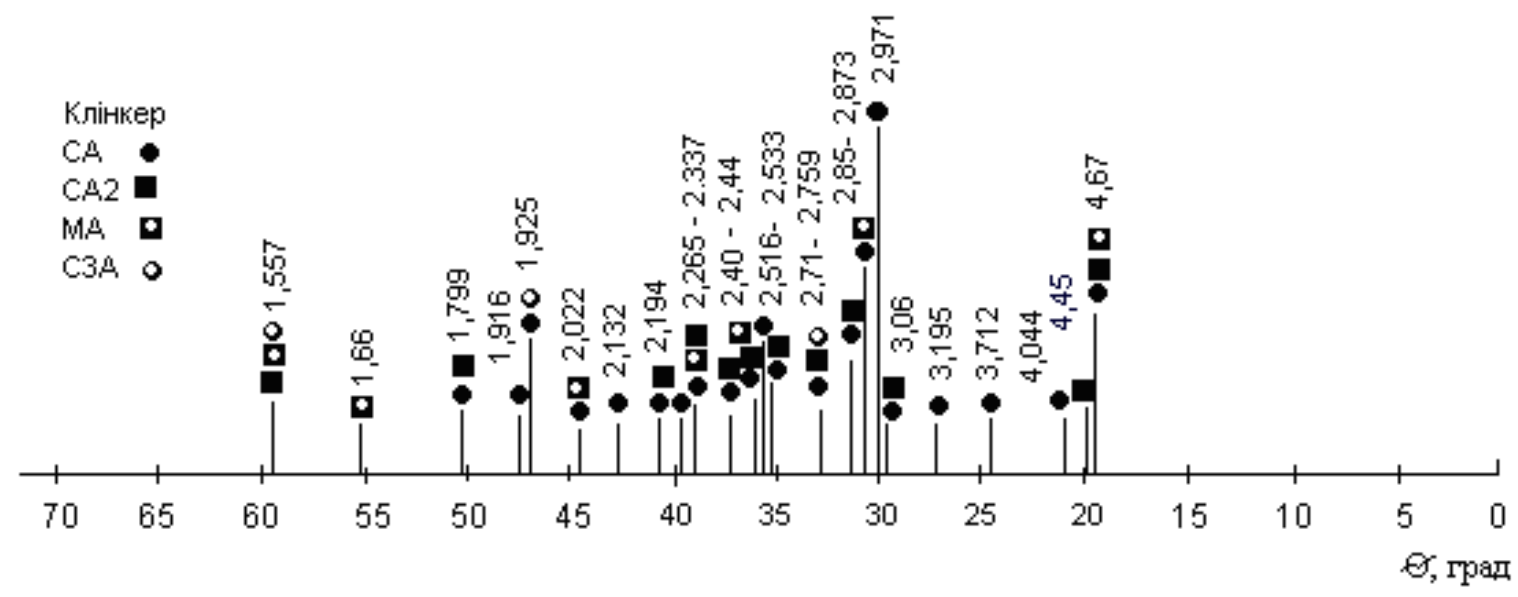

Рис. 2. Рентгенограма клінкеру

Таким чином, комплексом сучасних фізико-хімічних методів аналізу встановлено, що основними клінкерними мінералами цементу на основі відходів водоочищення $\epsilon$ моноалюмінат i діалюмінат кальцію, а також магнезіальна шпінель.

Оптимальним складом є склад № 1 , оскільки він має найвищі показники міцності. Рентгенограми цементного каменю у віці 7 і 28 діб не відрізняються один від одного, про що свідчать дані, отримані за допомогою рентгенографічного аналізу.

На рентгенограмі гідратованого цементу (рис. 3) чітко ідентифікуються дифракційні максимуми гідроалюмінатів кальцію: $\mathrm{CAH}_{10}(7,16 ; 3,559 ; 2,533 ; \AA)$, $\mathrm{C}_{4} \mathrm{AH}_{13} \quad(4,672 ; 4,453 ; 4,044 ; 2,873 ; 2,85$; $2,439 ; 2,328 \AA)$, гібсит $\mathrm{Al}(\mathrm{OH})_{3}(4,87 ; 4,379$; $2,378 ; \AA), \mathrm{CA}(2,971 ; 3,297 ; 3,195 ; 3,058 \AA)$ та $\mathrm{CA}_{2}(3,503 ; 2,597 ; 2,42 ; \AA)$, магнезільна шпінель МА $(7,42 ; 2,85 ; \AA)$. 


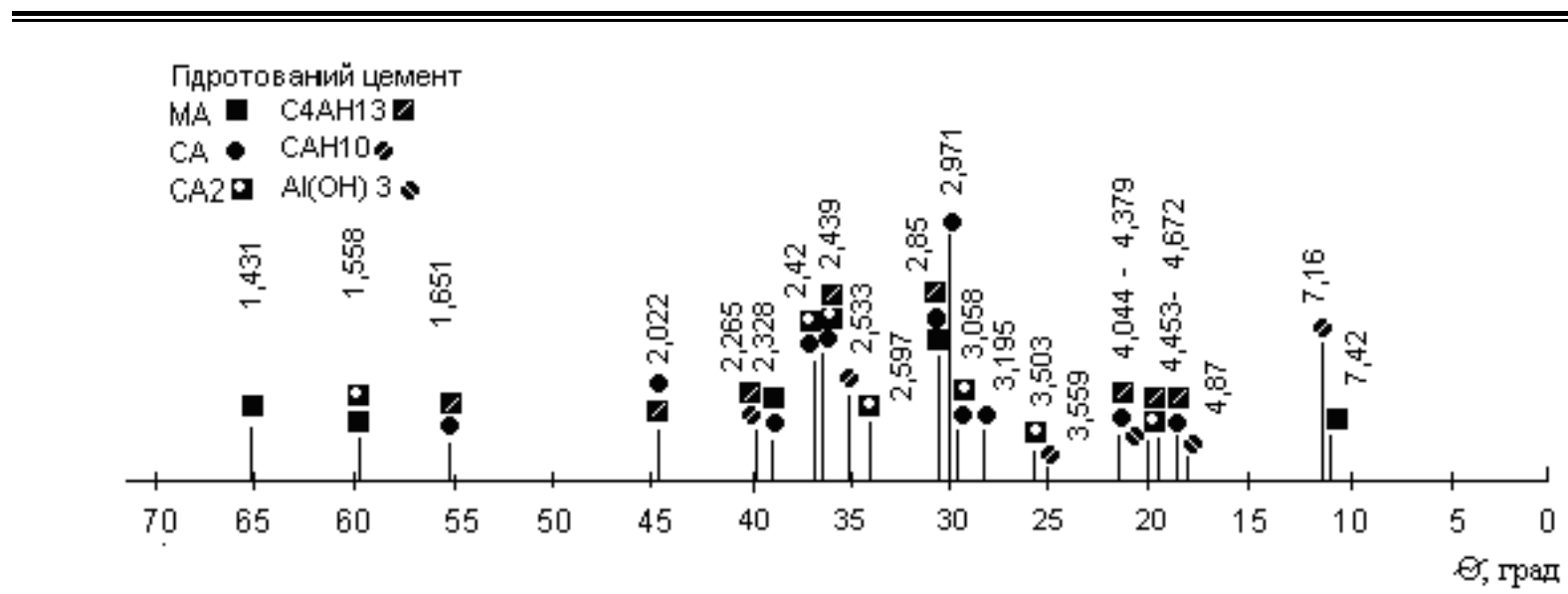

Рис. 3. Рентгенограма гідратованого цементу

Висновок. Таким чином, проведені дослідження дозволили встановити, що висока міцність цементу обумовлена вмістом у ньому гідроалюмінатів кальцію різної основності, гідроксиду алюмінію, а також непрогідратованих зерен алюмінатів кальцію та магнію, які в даному випадку є центрами кристалізації. Саме таке поєднання фаз як в кристалічному, так i колоїдному стані і забезпечує високу міцність цементного каменю.

\section{Список літератури}

1. Кузнецова, Т.В. Глиноземистый цемент [Текст] / Т.В. Кузнецова, Й. Талабер - М.: Стройиздат, 1988. - 265 с.

2. Мельник, М.Т. Огнеупорные цементы [Текст] / М.Т. Мельник, Н.Г. Илюха, Н.Н. Шаповалова. - К.: Вища школа, 1984. - 121 с.

3. Бутт, Ю.М. Химическая технология вяжущих материалов / Ю.М. Бутт, М.М. Сычев, В.В. Тимашев. - М.: Высшая школа, 1980. - 472 с.

4. Получение материалов специального назначения на основе отходов очистки сточных вод химических производств [Текст] / А.Н. Кожанова, Г.Н. Шабанова, Е.А. Семенченко, Я.Н. Питак // Современные проблемы химической технологии неорганических веществ: междунар. науч.-техн. конф. (22 - 25 мая 2001 г.): сб. науч. тр. - Одесса: Астропринт, 2001. - Т. 2. - C. 67-69.

5. Фізико-хімічні дослідження клінкеру цементу, отриманого з відходів водоочищення [Текст] / О.О. Семенченко, Г.М. Шабанова, 3.І. Ткачова, С.3. Зеленцов // Вестник Харьковского государственного политехнического университета. - Харьков: ХГПУ, 2000. Вып. 123. - С. 77-80.

6. Получение вяжущих материалов на основе отходов очистки сточных вод [Текст] / Г.Н. Шабанова, Е.А. Гапонова, Н.К. Вернигора, Н.С. Цапко [и др.] // Научные исследования, наносистемы и ресурсосберегающие технологии в стройиндустрии: междунар. научн.-практ. конф. (18-19 сент. 2007 г.): сб. докл. - Белгород: БГТУ, 2007. - С. 308-311.

7. К вопросу об использовании отходов водоочистки в производстве глиноземистого цемента [Текст] / Г.М. Шабанова, Р.М. Ворожбиян, А.Н. Корогодская // Вісник Національного технічного університету «ХПІ». - Харків: НТУ «ХПІ», 2011. - ВиП. 27. C. 164-173.

8. Установление возможности использования отходов промышленности в производстве глиноземистого цемента / Г.М. Шабанова, Р.М. Ворожбиян, А.Н. Корогодская, О.В. Костыркин // Зб. наук. праць. - Вип. 122. - Харків: УкрДАЗТ, 2011. - С. 288-292. 
Ключові слова: цемент, в’яжучі матеріали, бетони, відходи водоочищення, відходи виробництва, алюмінати кальцію, дифракційні максимуми, клінкер.

\section{Анотації}

У статті наведені результати досліджень сировинного матеріалу на базі відходів водоочищення Горлівського ВАТ “Концерн Стірол”. Результати аналізу шламу дають можливість використовувати його у вигляді сировинного компонента глиноземистого цементу. Актуальністю даної теми є не тільки зниження витрат на сировинні матеріали, але й поліпшення навколишнього екологічного середовища.

В статье приведены результаты исследований сырьевого материала на базе отхода водоочистки Горловского ОАО "Концерн Стирол". Результаты анализа шлама дают возможность использовать его в виде сырьевого компонента глиноземистого цемента. Актуальностью данной темы является не только снижение затрат на сырьевые материалы, но и улучшение окружающей экологической среды.

The article presents the results of investigations on the basis of raw material waste water treatment of Gorlovskij "Stirol". The results of sludge analysis give an opportunity to use it as a raw material component alumina cement. Relevance of the topic is based on not only lower costs for raw materials, but also the improvement of the ecological environment. 